Dicle Tıp Dergisi / Dicle Med J (2018) 45 (3) : 297-307

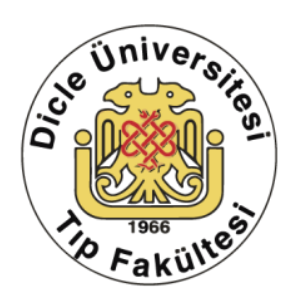

WWW.diclemedj.org

Özgün Araștırma / Original Article

\title{
Gebelikte Tütün Dumanı Maruziyetinin Anne Sıçan Akciğer Dokusunda Meydana Getirdiği Değiş̧iklikler Üzerine Alfa Lipoik Asitin Etkilerinin İncelenmesi
}

\author{
Elif Erdem Güzel' ${ }^{1}$ Nalan Kaya ${ }^{2}$, Gonca Ozan Kocamüftüoğlu³ ${ }^{3}$ Mehmet Ali Kısaçam4, \\ Dürrin Özlem Dabak ${ }^{5}$, İbrahim Enver Ozan 6
}

1 Mardin Artuklu Üniversitesi Sağlık Yüksekokulu, Mardin, Türkiye ORCID: 0000-0002-2097-7818

2 Firat Üniversitesi Tıp Fakültesi Histoloji ve Embriyoloji Anabilim Dalı, Elazı̆̆, Türkiye ORCID: 0000-0001-8880-4932

3 Firat Üniversitesi Veteriner Fakültesi Biyokimya Anabilim Dalı, Elazığ, Türkiye ORCID: 0000-0001-6874-3669

4 Fırat Üniversitesi Veteriner Fakültesi Biyokimya Anabilim Dalı, Elazığ, Türkiye ORCID: 0000-0003-0521-9434

5 Firat Üniversitesi Tıp Fakültesi Histoloji ve Embriyoloji Anabilim Dalı, Elazığ, Türkiye ORCID: 0000-0001-7210-6873

6 Fırat Üniversitesi Tıp Fakültesi Histoloji ve Embriyoloji Anabilim Dalı, Elazı̆̆, Türkiye ORCID: 0000-0002-7274-5138

Geliş: 06.02.2018, Revizyon: 19.04.2018, Kabul Tarihi: 07.05.2018

$\ddot{0} \mathbf{z}$

Amaç: Çalışmamızda gebelikte tütün dumanına maruz kalan anne sıçanların akciğer dokusunda meydana gelen değişiklikler üzerine alfa lipoik asitin etkilerinin deneysel sıçan modeli üzerinde araştırılması amaçlandı.

Yöntemler: Çalışmada 28 adet dişi Sprague-Dawley cinsi sıçanlar kullanıldı. Gebe sıçanlar; Kontrol grubu, Tütün dumanı (TD) grubu, Tütün dumanı + Alfa lipoik asit (TD+ALA) grubu ve Alfa lipoik asit (ALA) grubu olmak üzere rastgele dört eşit gruba ayrıldı. TD ve TD+ALA grubundaki sıçanlar çiftleşmeden önce sekiz hafta ve gebelik süresince günde iki saat tütün dumanına maruz birakıld.

TD+ALA ve ALA grubundaki sıçanlara ise çiftleşmeden önce sekiz hafta ve gebelik süresince gün aşırı oral gavaj yolu ile 20 mg/kg dozunda alfa lipoik asit verildi. Deneyin sonunda sıçanlar dekapite edilerek akciğer dokuları çıkarıldı ve histolojik, biyokimyasal ve immünohistokimyasal metotlar uygulandı.

Bulgular: TD grubuna ait akciğer kesitlerinde inflamatuar hücre artışı, konjesyon, ödem, hemoraji gibi histopatolojik bulgular gözlendi. ALA uygulamasıyla bu histopatalojik bulgularda istatistiksel olarak anlamlı oranda düzelmeler izlendi. TD grubunda VEGF immünreaktivitesinin kontrol grubuna göre anlamlı artış gösterdiği, TD+ALA grubunda ise TD grubuna göre VEGF immünreaktivitesinin anlamlı derecede azaldığı belirlendi. TD grubunda MDA değerlerinin kontrole göre anlamlı derecede arttığı, TD+ALA grubunda ise TD grubuna göre anlamlı derecede azaldığı gözlendi.

Sonuç: Tütün dumanının gebe sıçan akciğerinde yol açtığı oksidatif hasarın, alfa lipoik asit tedavisinin antioksidan etkileri ile kısmen engellendiği belirlendi.

Anahtar Kelimeler: Gebelik, tütün dumanı, alfa lipoik asit, akciğer, sıçan.

DOI: $10.5798 /$ dicletip.457249

Yazıșma Adresi / Correspondence: Elif Erdem Güzel, Mardin Artuklu Üniversitesi/Sağlık Yüksekokulu, Hemșirelik Bölümü Mardin, Türkiye e-mail: elfer192@hotmail.com 


\title{
Investigation of the Effects of Alpfa Lipoic Acid on Changes in Maternal Rat Lung Caused by Tobacco Smoke Exposure in Pregnancy
}

\begin{abstract}
Objectives: The aim of our study was to investigate the effects of alpha lipoic acid on changes in the lung tissue of mothers exposed to tobacco smoke during pregnancy on an experimental rat model.

Methods: In the study, twenty-eight Spraque-Dawley female rats were used. Rats were randomly divided into four groups: Control, tobacco smoke (TS), tobacco smoke + alpha lipoic acid (TS+ALA) and alpha lipoic acid (ALA). Rats in the TS and TS+ALA groups were exposed to tobacco smoke twice a day for one hour starting from eight weeks before mating and during pregnancy. $20 \mathrm{mg} / \mathrm{kg}$ of ALA was administered to ALA and TS+ALA group via oral gavage. At the end of the experiment, the rats were decapitated and lung tissues were removed and histological, biochemical and immunohistochemical methods were applied.

Result: Histopathological findings such as inflammatory cell enlargement, congestion, edema, hemorrhage were observed in lung sections of TS group. Statistically significant improvement was observed in these histopathological findings with ALA application. VEGF immunoreactivity was significantly increased in TS group compared to control group and VEGF immunoreactivity decreased significantly in TS + ALA group according to TS group. It was observed that the MDA levels in the group of tobacco smoke increased with respect to the control, whereas those in the TS +ALA group decreased significantly with respect to the TS group.

Conclusion: The oxidative damage caused by tobacco smoke in the pregnant rat lung was partially inhibited by the antioxidant effects of alpha lipoic acid treatment.
\end{abstract}

Keywords: Pregnancy, tobacco smoke, alpha lipoic acid, lung, rat.

\section{GíRiş}

Çevresel tütün dumanı (ÇTD), iki solunan sigara arasındaki bekleme süresinde açığa çıkan ana akım dumanı ve yanan bir sigaranın ucundan çıkan yan akım dumanından oluşur ${ }^{1}$. Yapılan çalışmalarda yan akım dumanına maruz kalanlarda polisiklik aromatik hidrokarbon (PAH), nitrozamin, aromatik amin, karbonmonoksit (CO), nikotin ve amonyak gibi toksik maddelerin daha yüksek olduğu tespit edilmiştir ${ }^{2,3}$. ÇTD maruziyetinin sigara içenlerdekine benzer şekilde vücutta hasar oluşturduğu ve önlenebilir ölüm nedenleri arasında üçüncü sırada yer aldığı bildirilmiştir ${ }^{4}$. Dünya Sağlık Örgütü (DSÖ)'nün raporunda, 15 yaş üzeri kadınlarda sigara içme sıklığının dünyada $\% 8$, Türkiye'de ise $\% 13,1$ olduğu rapor edilmiştir ${ }^{5,6}$. Gebelikte pasif içicilik oranlarının ise oldukça yüksek olduğu, sigara dumanı maruziyetinin hem anne sağlığını hem de fetüs ve yenidoğan sağlığını olumsuz etkilediği bildirilmiştir7,8.
Tütün dumanı serbest radikallerin kaynağıdır. Artan serbest radikaller kronik obstrüktif akciğer hastalığı (KOAH), idiopatik pulmoner fibrozis (IPF), kronik bronşit, amfizem ve astım gibi malign olmayan solunum hastalıklarıyla ilişkilendirilmiştir9 ${ }^{9}$ Solunan tütün dumanı, akciğer dokusunda azot ve reaktif oksijen türlerinin üretilmesine ve bunu takiben inflamatuar hücrelerin aktivasyonuna ve endotelyal hasara yol açar ${ }^{4}$. Değişen vasküler endotelyal büyüme faktör (VEGF) ekspresyonlarının akciğerlerde gözlenen bu hasarlarla bağlantılı olduğu, akciğer kapiller fonksiyonunu ve geçirgenlik artışını etkilediği, akciğer tamiri ve yeniden modellenmesinde önemli rol oynadığ Antioksidan kullanımının akciğer dokusundaki VEGF ekspresyonlarını değiştirdiği bilinmektedir11. Alfa lipoik asit (ALA) gibi antioksidanların çeşitli dokularda peroksil ve $\mathrm{OH}$ - radikalleri gibi birçok reaktif oksijen türlerini süpürerek oksidatif stresi azalttığı ve serbest radikal kaynaklı histopatolojik 
tablonun iyileşmesine katkı sunduğu rapor edilmiştir ${ }^{12}$.

$\mathrm{Bu}$ çalışmanın amacı; gebelikte tütün dumanına maruz kalan anne sıçan akciğer dokularında meydana gelen değişiklikler üzerine ALA' nın etkilerinin incelenmesidir.

\section{YÖNTEMLER}

Çalışma Fırat Üniversitesi Hayvan Deneyleri Etik Kurulu'nun 2017/23 toplantı sayılı kararı gereğince etik yönden uygun bulunarak yapıldı. Çalışmada FÜDAM'dan temin edilen ortalama ağırlığı $160 \pm 10$ gr olan 28 adet 6 haftalık Sprague-Dawley cinsi dişi sıçanlar ile dişi sıçanların gebe kalması için gerekli 28 adet Sprague-Dawley cinsi erişkin erkek sıçanlar kullanıldı. Her kafeste bir dişi sıçan ile bir erişkin erkek sıçan olacak şekilde çiftleştirilme gerçekleştirildi ve vajinal smearda spermin gözlendiği tarih embriyonik 0. gün olarak kabul edildi. Deney hayvanları FÜDAM hayvan laboratuvarında deney süresince standart sıçan pelet yemi ve musluk suyu ile 12 saat (07:0019:00) aydınlık-12 saat (19:00- 07:00) karanlık periyodunda, $21 \pm 1^{\circ} \mathrm{C}$ ortam sicaklığında beslendi. Gebe sıçanlar; Kontrol grubu, Tütün dumanı (TD) grubu, Tütün dumanı + Alfa lipoik asit (TD+ALA) grubu ve Alfa lipoik asit (ALA) grubu olmak üzere rastgele dört eşit gruba ayrıldı $(n=7)$. TD ve TD+ALA grubundaki dişi sıçanlar, çiftleşmeden önce sekiz hafta ve gebelik süresince günde iki defa birer saat tütün dumanına maruz bırakıldı. TD+ALA grubundaki sıçanlara tütün dumanına ilaveten $20 \mathrm{mg} / \mathrm{kg}$ dozunda alfa lipoik asit gün aşırı oral gavaj yolu ile verildi. ALA grubundaki sıçanlara ise belirtilen süre boyunca sadece $20 \mathrm{mg} / \mathrm{kg}$ dozunda alfa lipoik asit gün aşırı oral gavaj yolu ile uygulandi ${ }^{13}$. Doğum ile birlikte bütün uygulamalar durduruldu. Tüm gruplardaki anne sıçanlar laktasyon dönemi bittikten sonra ketamin $(75 \mathrm{mg} / \mathrm{kg})$ ve xylazine $(10 \mathrm{mg} / \mathrm{kg})$ anestezisi altında dekapite edilerek, akciğer dokuları çıkarıldı.

Deney Düzeneği ve Tütün Dumanının Verilmesi
Tütün dumanı uygulaması 150x50x50 boyutlarında kapağı üstten açılabilir şekilde özel bir cam kafes içerisinde gerçekleştirildi. 10 gramlık tütünün yanması ile ortaya çıkan duman, akvaryum hava pompası (AP-001 XÍLONG Aquarium Air Pump, China) aracılığıyla cam kafes içerisine verildi. Tütün dumanı verilecek her bir gruba ait sıçanlar, ayrı kafeslerde olacak biçimde bu düzenek aracılığıyla deney süresi boyunca her gün 9:0010:00 ve 14:00-15:00 saatleri arası toplam iki saat dumana maruz birakıldılar.

\section{Histolojik Takip ve Boyama}

Histopatolojik değerlendirmeler için 24 saat süre ile \%10'luk formaldehit içerisinde fikse edilen akciğer dokuları fiksasyon işleminin ardından 24 saat boyunca çeşme suyu altında yıkandı. Yıkanan dokular rutin histolojik takip serilerinden geçirilerek parafin bloklara gömüldü. Parafin bloklardan $5 \mu \mathrm{m}$ kalınlığında kesitler alındı. Elde edilen preparatlar Hematoksilen-Eozin ile boyanarak $1 s ̧ ı$ mikroskobu altında (Novel $\mathrm{N}-800 \mathrm{M}$ ) incelenip fotoğraflandı. Değişiklikler histopatolojik durumlarına göre yok (0), hafif (1), orta (2) ve şiddetli (3) olarak değerlendirilerek histoskor tablosu çıkarıldı ${ }^{14}$.

\section{İmmunohistokimyasal Boyama}

Akciğer dokusunda VEGF immünreaktivitesinin belirlenmesi için, soğutulmuş parafin bloklardan polilizinli lamlara 5 ?m kalınlığında kesitler alındı. Ksilol ile deparafinizasyon ve şeffaflaştırma işleminden sonra dokular azalan dereceli alkol serilerinden geçirilip antigen retrieval için sitrat tampon solüsyonunda $\mathrm{pH}$ : 6'da mikrodalga firında (750W) 12 dakika kaynatıldı. Endojen peroksidaz aktivitesini önlemek için hidrojen peroksit bloker (TA-125HP Lot No: HP18180, Hydrogen Peroxide Block, Thermo Scientific) ile muamele edildi. Zemin boyasını engellemek için 5 dakika Ultra V Block (TA-125-UB, Ultra V Block, Thermo Scientific) uygulamasindan sonra primer antikor (RB9031-P lot No: 9031P1505A, Polyclonal AntiVEGF Antibody) damlatılan dokular 60 dakika 
oda ısısında karanlık ve nemli ortamda inkübe edildi. İnkübasyondan sonra dokular sekonder antikor (TP-060-BN, Biotinylated Goat AntiPoliyvalent (anti-mouse / rabbit IgG), Thermo Scientific) ile muamele edildi. Negatif kontrol olarak kullanılan dokularda ise primer antikor yerine PBS (Phosphate Buffered Saline) kullanıldı, diğer basamaklarda herhangi bir değişiklik yapılmadı. Mayer's hematoksilen ile zit boyaması yapılan dokular PBS ve distile sudan geçirilerek uygun kapatma solüsyonu ile kapatıldı. Hazırlanan preparatlar ışık mikroskobunda (Novel N-800M) incelenerek değerlendirildi ve fotoğraflandı. İmmünohistokimyasal boyanmanın değerlendirilmesinde; immünreaktivitenin yaygınlığı $(0.1:<\% 25,0.4: \% 26-50,0.6$ : \%5175, 0.9: \%76-100) ve şiddeti (0: yok, +0.5: çok az, +1: az, +2: orta, +3: şiddetli) esas alınarak histoskor tablosu oluşturuldu ${ }^{15}$.

\section{Biyokimyasal Analiz}

Dekapitasyondan sonra çıkarılan akciğer dokuları serum fizyolojik ile yıkanıp $-200^{\circ} C^{\prime}$ de çalışma gününe kadar saklandı. Çözdürülen doku örnekleri \%1.15'lik KCl ile 1:100 oranında (ağırlık/hacim) sulandırılıp homojenize edildikten sonra, 3500 rpm'de 15 dakika santrifüj edildi. Elde edilen süpernatantlarda malondialdehit (MDA) tayini Placer metoduna göre yapıldı16. $\mathrm{Bu}$ metodun temeli lipit peroksidasyonu sonucu oluşan aldehit ürünlerinden biri olan MDA ile tiobarbitürik asit (TBA)'in reaksiyonuna dayanmaktadır. Reaksiyon sonucunda pembe renkli bir kompleks oluşmakta ve çözeltinin absorbansı 532 nm'de spektrofotometrik olarak ölçülerek lipit peroksidasyonunun derecesi belirlenmektedir.

\section{Ístatistiksel Analiz}

Tüm istatistiksel analizler SPSS 22.0 (Statistical Package for Social Sciences) paket programında yapıldı. Veriler ortalama \pm standart sapma değerleri olarak sunuldu. $\mathrm{p}<0.05$ değeri anlamlı olarak kabul edildi.
Normal dağılım gösteren çoklu grupların aralarındaki farklılıkları test etmek için Tek Yönlü Varyans Analizi (ANOVA) uygulandı. İkili karşılaştırmalar için ise Post-hoc Tukey testi kullanıldı.

\section{BULGULAR}

\section{Işsı Mikroskobik Bulgular}

Kontrol grubuna ait akciğer kesitlerinde bronş, bronşiyol, alveol ve pulmoner interstisyum yapıları normal olarak izlendi (Şekil 1). TD grubuna ait akciğer kesitlerinde peribronşiyal, interstisyel ve perivasküler alanlarda inflamatuar hücre artışı, hemorajik alanlar, konjesyon, ödem, vasküler duvar kalınlığında artış, bazı bronş ve bronşiyol epitellerinde dejenerasyon ve bozulmalar, alveoler kanallarda genişlemeler ve bazı alanlarda kollabe alveoller ile hiyalin membran oluşumları izlendi (Şekil 2, 3, 4, 5). TD+ALA grubuna ait akciğer kesitlerinde TD grubuna göre bütün histopatolojik bulgularda istatistiksel olarak anlaml azalma izlendi $(\mathrm{p}<0.05)$. Bunun yanı sira hiyalin membran yapılarına rastlanmadı (Şekil 6, 7 ). ALA grubuna ait akciğer kesitlerinde bronş, bronşiyol, alveol ve pulmoner interstisyum yapıları kontrol grubuna yakın şekilde normal histolojik yapıda izlendi ( $>>0.05) \quad$ (Şekil 8) (Tablo I).

\section{İmmünreaktive Bulguları}

VEGF immünreaktivitesi için yapılan immünohistokimyasal boyamanın ışık mikroskobu altında incelenmesi sonucu; kontrol grubuna ait VEGF immünreaktivitesi akciğer dokusunda bronş, bronşiyol ve alveol epitellerinde, düz kas hücrelerinde ve subepitelyal matriks hücrelerinde gözlendi (Şekil 9, 10, 11, 12). TD grubunda, kontrol grubu ile karşılaştırıldığında anlamlı bir artış vardı $(\mathrm{p}<0.05)$ (Şekil 10). TD+ ALA grubunda ise, TD grubu ile kıyaslandığında istatistiksel olarak anlamlı bir azalma gözlendi $(p<0.05)$ (Şekil 11). ALA grubuna ait VEGF 
immünreaktivitenin kontrol grubuna yakın olduğu gözlendi ( $\mathrm{p}>0.05)$ (Şekil 12) (Tablo II).

Tablo 1: Akciğer dokusundaki histolojik değerlendirmelere ait histoskor tablosu

\begin{tabular}{|llllll|}
\hline & Kontrol & TD & TD+ALA & ALA & ${ }^{*}$ p \\
\hline Hemoraji & $0,14 \pm 0,37$ & $2,28 \pm 0,75^{\mathrm{a}}$ & $1,28 \pm 0,48^{\mathrm{ab}}$ & $0,28 \pm 0,48^{\mathrm{b}}$ & $<0.05$ \\
Konjesyon & $0,28 \pm 0,48$ & $2,14 \pm 0,69^{\mathrm{a}}$ & $1,14 \pm 0,37^{\mathrm{ab}}$ & $0,28 \pm 0,48^{\mathrm{b}}$ & $<0.05$ \\
İnfiltrasyon & $0,00 \pm 0,00$ & $2,85 \pm 0,03^{\mathrm{a}}$ & $1,28 \pm 0,48^{\mathrm{ab}}$ & $0,00 \pm 0,00^{\mathrm{b}}$ & $<0.05$ \\
Ödem & $0,00 \pm 0,00$ & $2,14 \pm 0,69^{\mathrm{a}}$ & $1,28 \pm 0,48^{\mathrm{ab}}$ & $0,00 \pm 0,00^{\mathrm{b}}$ & $<0.05$ \\
$\begin{array}{l}\text { Vasküler duvar } \\
\text { kalınlığında artış }\end{array}$ & $0,00 \pm 0,00$ & $2,14 \pm 0,37^{\mathrm{a}}$ & $1,42 \pm 0,53^{\mathrm{ab}}$ & $0,00 \pm 0,00^{\mathrm{b}}$ & $<0.05$ \\
Epitel dejenerasyonu & $0,28 \pm 0,48$ & $2,00 \pm 0,00^{\mathrm{a}}$ & $1,14 \pm 0,37^{\mathrm{ab}}$ & $0,28 \pm 0,48^{\mathrm{b}}$ & $<0.05$ \\
Hiyalin membran & $0,00 \pm 0,00$ & $2,00 \pm 1,00^{\mathrm{a}}$ & $0,00 \pm 0,00^{\mathrm{b}}$ & $0,00 \pm 0,00^{\mathrm{b}}$ & $<0.05$ \\
Kollabe alveol & $0,00 \pm 0,00$ & $2,42 \pm 0,53^{\mathrm{a}}$ & $1,00 \pm 0,57^{\mathrm{ab}}$ & $0,00 \pm 0,00^{\mathrm{b}}$ & $<0.05$ \\
\hline
\end{tabular}

Değerler ortalama \pm standart sapma olarak verilmiştir.

aKontrol grubuna göre karşılaştırıldığında

bTütün dumanı grubuna göre karşılaş̧tırıldığında

* İstatistiksel anlamlılık ( $\mathrm{p}<0.05)$

Tablo 2: Akciğer dokusundaki VEGF immünreaktivitesi

\begin{tabular}{|llc|}
\hline GRUPLAR & $\begin{array}{l}\text { HISTOSKOR } \\
\text { (yayginlık x şiddet) }\end{array}$ & ${ }^{*} \mathbf{p}$ \\
\hline Kontrol & $1,38 \pm 0.12$ & \\
TD & $2,58 \pm 0.11^{\mathrm{a}}$ & $<0.05$ \\
TD + ALA & $1,95 \pm 0.17^{\mathrm{ab}}$ & $<0.05$ \\
ALA & $1,26 \pm 0.12^{\mathrm{b}}$ & $<0.05$ \\
\hline
\end{tabular}

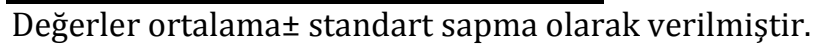
aKontrol grubuna göre karșılaștırıldı̆̆ında bTütün dumanı grubuna göre karşılaştırıldığında

* İstatistiksel anlamlılık ( $\mathrm{p}<0.05)$

Tablo 3: Akciğer dokusundaki MDA düzeyleri

\begin{tabular}{|lll|}
\hline GRUPLAR & $\begin{array}{l}\text { MDA } \\
\text { (nmol/g doku) }\end{array}$ & ${ }^{*} \mathbf{p}$ \\
\hline Kontrol & $68,681 \pm 3,58$ & \\
TD & $93,616 \pm 4,50^{\mathrm{a}}$ & $<0.05$ \\
TD+ ALA & $72,468 \pm 3,87^{\mathrm{b}}$ & $<0.05$ \\
ALA & $67,570 \pm 4,83^{\mathrm{b}}$ & $<0.05$ \\
\hline
\end{tabular}

Değerler ortalama \pm standart sapma olarak verilmiştir. aKontrol grubuna göre karşılaştırıldığında bTütün dumanı grubuna göre karşılaştırıldığında

* İstatistiksel anlamlılık ( $\mathrm{p}<0.05)$

\section{Biyokimyasal Bulgular}

Yapılan değerlendirmelerde lipit peroksidasyonunun göstergesi olan MDA düzeylerinin TD grubunda kontrol grubu ile karşılaştırıldığında istatistiksel olarak anlamlı düzeyde arttığı belirlendi $(\mathrm{p}<0.05)$. TD+ ALA grubunda ise TD grubuna göre anlamlı düzeyde azalarak kontrol grubuna yakın düzeylerde olduğu saptandi $(\mathrm{p}<0.05)$

\section{TARTIŞMA}

Sigara dumanı toksik, mutajenik ve kanserojen etki gösteren ve birçok hastalık için çevresel risk faktörü oluşturan 4000'den fazla madde içerir ${ }^{17}$. Etkili metabolik mekanizmalarla bu maddeler aktif metabolitlere dönüștürülerek DNA hasarına ve mutasyona sebep olur ${ }^{18}$. Sigaranın gebelik boyunca kullanımı veya maruziyeti birçok olumsuz sonuçlar doğurur. Yapılan çalışmalarda sigaraya bağlı olarak artan oksidan ve azalan antioksidan seviyelerinin tekrarlayan gebelik kayıplarıyla ilişkili olduğu, meydana gelen oksidatif stresin abortus, preeklampsi ve gebelik komplikasyonlarının patolojisinde rol oynadığı ortaya koyulmuştur ${ }^{19,20}$. 


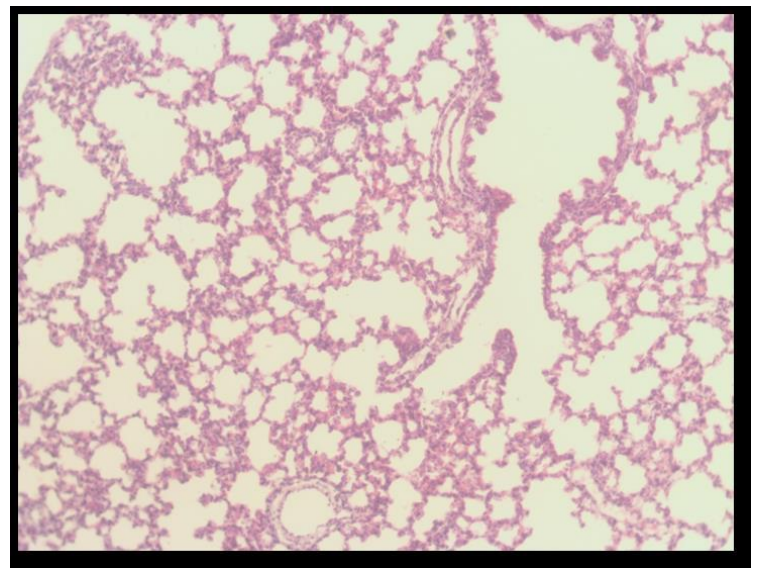

Şekil 1: Kontrol grubuna ait normal akciğer histolojisi. (H\&E x10).

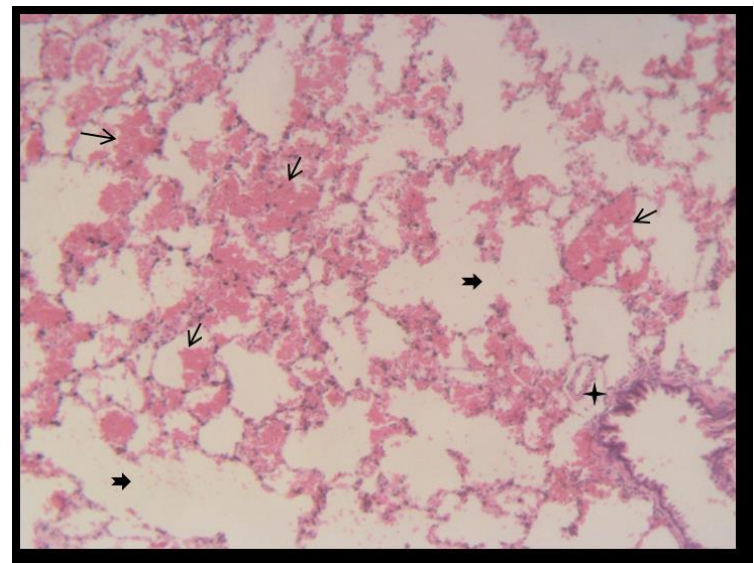

Şekil 2: Tütün dumanı grubuna ait akciğer doku kesitindeki hemorajik alanlar $(\rightarrow)$, ödem ( ) ve alveol kanallarında genişleme ( ) (H\&E x10).

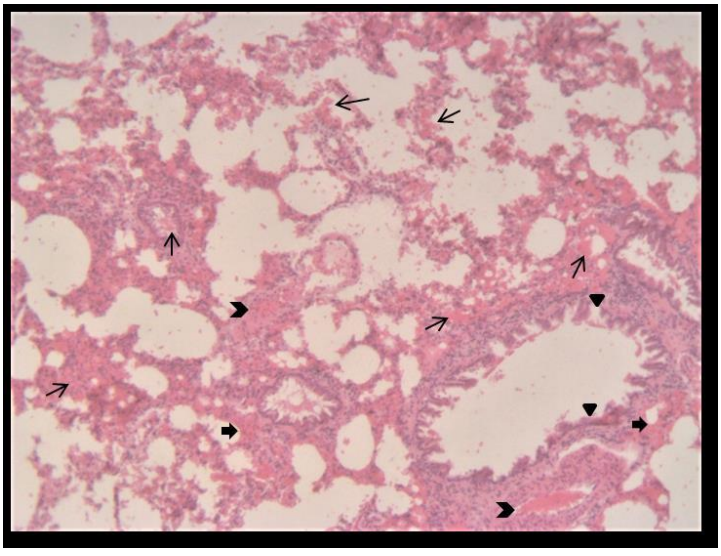

Şekil 3: Tütün dumanı grubuna ait akciğer doku kesitindeki hemorajik alanlar $(\rightarrow)$, konjesyon $(\boldsymbol{\nabla})$, hiyalin membran oluşumları $(\overrightarrow{)})$, epitel dejenerasyonu $(\boldsymbol{\nabla})(\mathrm{H} \& \mathrm{E} \mathrm{x} 10)$.

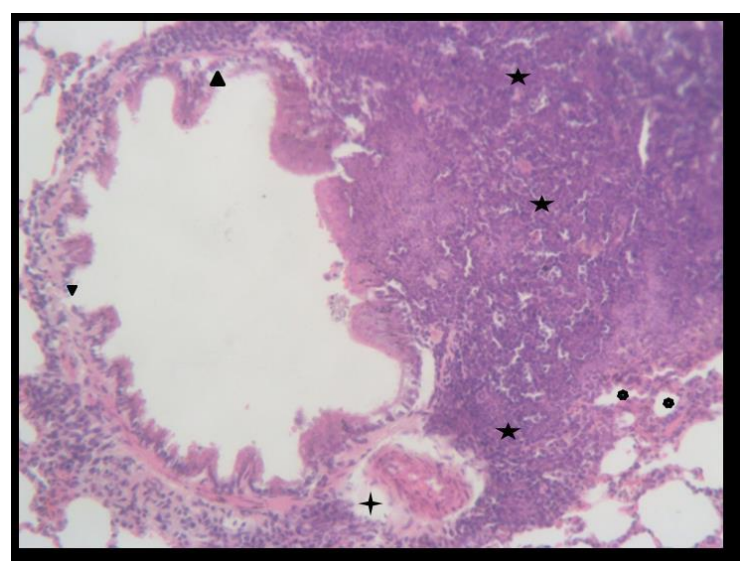

Şekil 4: Tütün dumanı grubuna ait akciğer doku kesitindeki inflamatuar hücre artışı $(\star)$, kollabe alveoller ( ), perivasküler ödem $(+)$ ve epitelde bozulma (A) (H\&E x20).

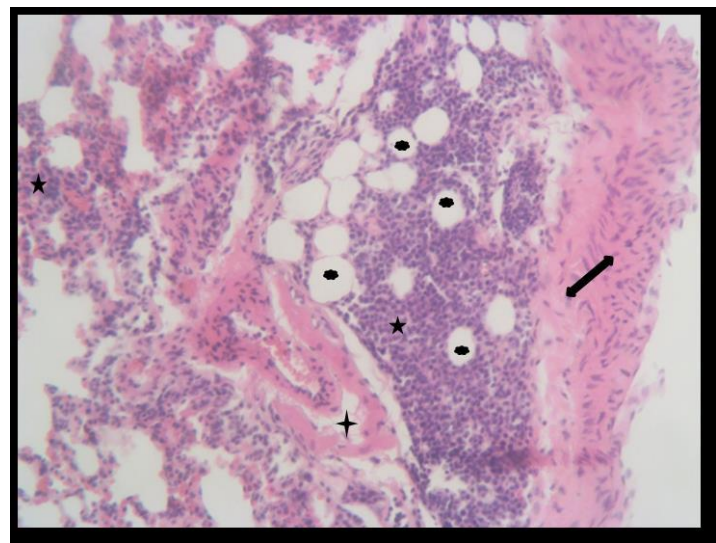

Şekil 5: Tütün dumanı grubuna ait akciğer doku kesitindeki inflamatuar hücre artışı $(\star)$, kollabe alveoller $(\bullet)$, perivasküler ödem $(+)$ ve vasküler duvar artışı (ノ) (H\&E x20).

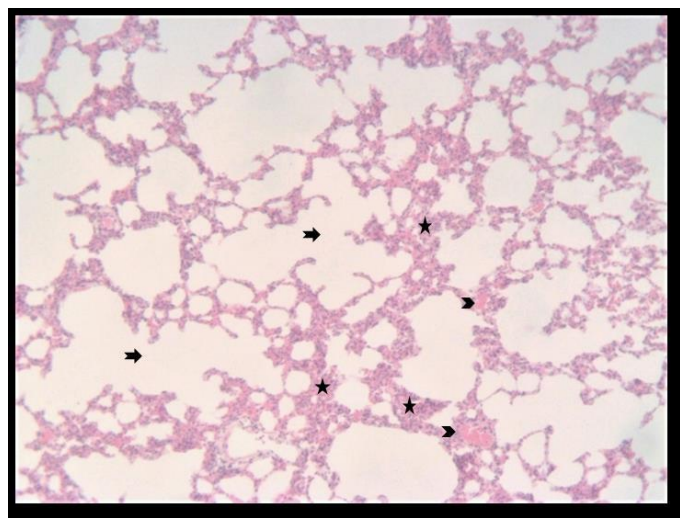

Şekil 6: Tütün dumanı+ALA grubuna ait akciğer doku kesitinde inflamatuar hücre artışı ( $\star$ ), konjesyon ( $\boldsymbol{( \boldsymbol { ) } )}$ ve alveol kanallarında genişleme $\Rightarrow$ ( $\Rightarrow \& E \times 10)$. 


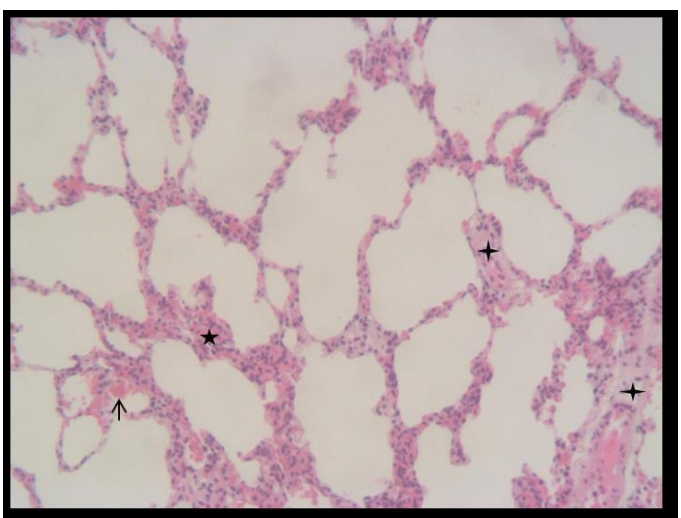

Şekil 7: Tütün dumanı+ALA grubuna ait akciğer doku kesitinde inflamatuar hücre artışı $(\star)$,

hemorajik alanlar $(\lambda)$ ve perivasküler ödem $(+)$ (H\&E x20).

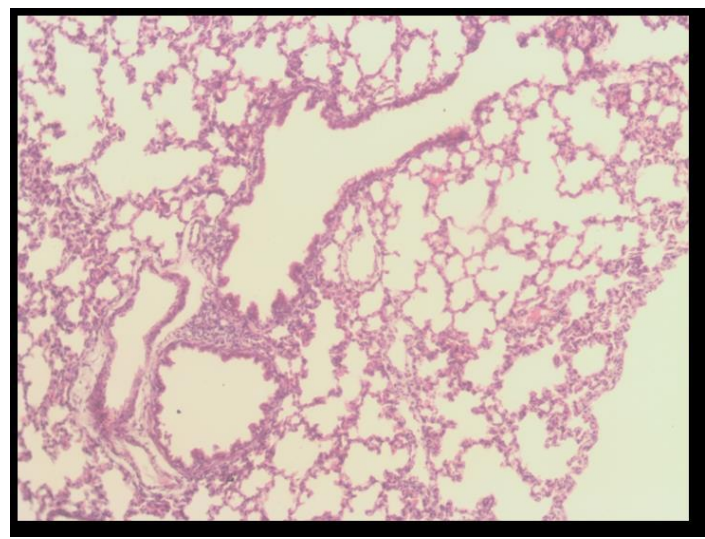

Şekil 8: ALA grubuna ait akciğer doku kesiti. (H\&E x10).

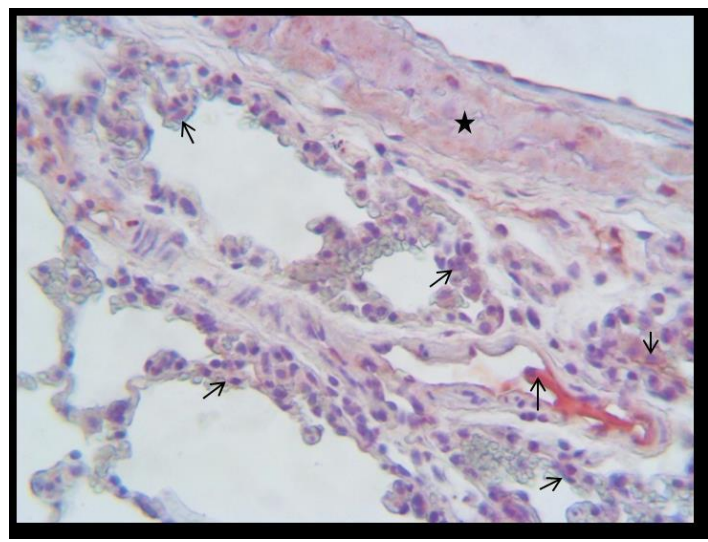

Şekil 9: Kontrol grubuna ait damar düz kas hücreleri $(\star)$ ve alveoler epitel hücrelerinde $(\lambda)$ VEGF immünreaktivitesi (x40).

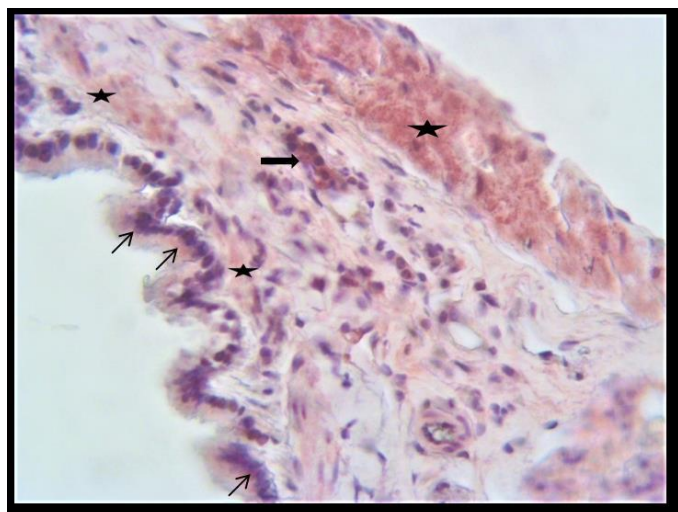

Şekil 10: Tütün dumanı grubuna ait damar ve bronşiyol düz kas hücrelerinde $(\star)$, bronşiyol epitel hücrelerinde ( $\boldsymbol{T}$ ), subepitelyal matrikste $(\rightarrow)$ artmış VEGF immünreaktivitesi (x40).

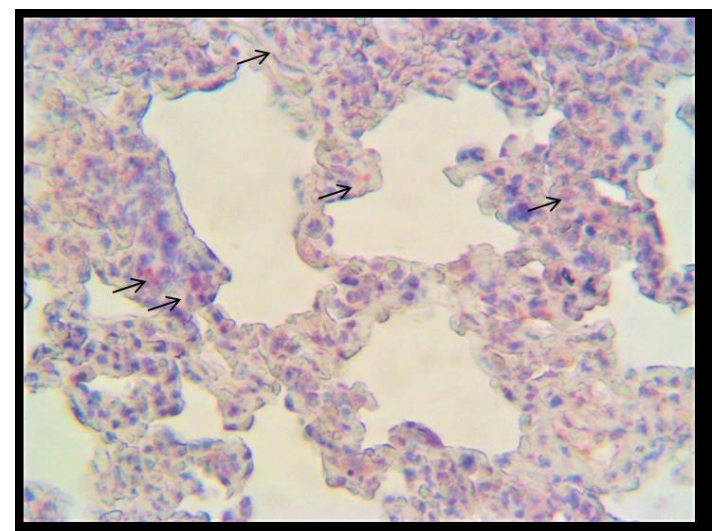

Şekil 11: Tütün dumanı+ALA grubuna ait alveoler epitel hücrelerinde ( $\boldsymbol{\lambda}$ ) VEGF immünreaktivitesi (x40).

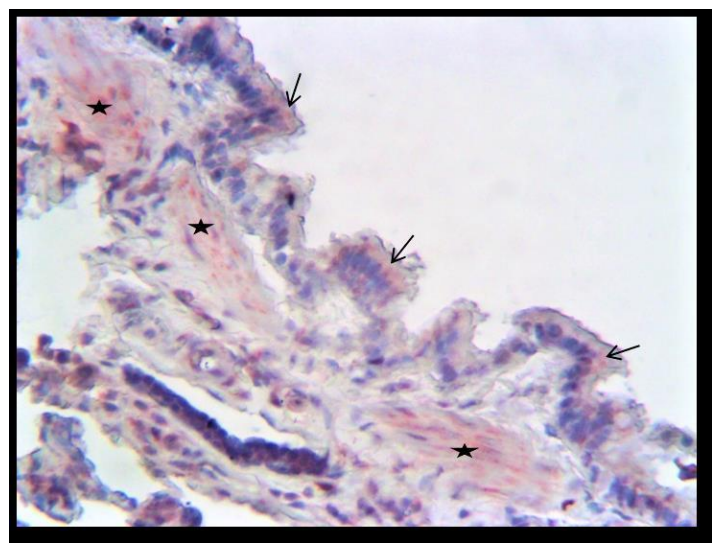

Şekil 12: ALA grubuna ait bronşiyal düz kas hücreleri $(\star)$ ve epitel hücrelerinde $(\lambda)$ VEGF immünreaktivitesi (x40). 
Sigara dumanı serbest radikallerin kaynağıdır. Serbest radikallerin, akciğerlerde inflamatuar hücre birikimine neden olduğu, bu inflamatuar hücrelerin ise litik enzimler ve serbest oksijen radikalleri üreterek alveoler ve interstisyel pulmoner yapı hasarına yol açabileceği bildirilmiştir ${ }^{21}$. Ayrıca serbest radikaller mikrovasküler yapılara hasar vererek, membran içeriğini ve transportunu değiștirir ${ }^{22}$. Yapılan bir çalışmada tütün dumanı maruziyeti sonucu sıçanlara ait akciğer damar duvarlarında kalınlaşma, perivasküler alanlarda lökositten zengin hücre infiltrasyonu, peribronşiyal ve interstisyel inflamasyon, vasküler konjesyon, alveoler bozulma ve alveoler makrofaj sayısında artış bulguları elde edilmiştir ${ }^{23}$. Çalışmamızda da tütün dumanı grubuna ait akciğer kesitlerinde benzer histopatolojik bulgular gözlenmiştir. Tütün dumanı kaynaklı artış gösteren inflamatuar hücrelerin serbest radikal üretimini daha da arttırarak pulmoner ödeme neden olabileceği ve pulmoner yapının hasarından sorumlu olabileceğini düşünmekteyiz.

Gebelikte sigara dumanı maruziyeti oksijen kaynağını sınırlayarak anne, fetüs ve yenidoğan sağlığı için risk oluşturur ${ }^{24}$. Gebelik süresince, tütün dumanındaki serbest radikaller, ağır metaller, CO ve nikotin içeriği dokulardaki iskemiyi güçlendirir ${ }^{25}$. Sigara dumanındaki CO, oksijen transferine müdahale ederek oksijen seviyesini azaltır ve dokuyu hipoksiye sokar. Hipoksiyi takip eden iskemi ise hasara neden olarak dokuyu patolojik bir sürece sokar. Sigara dumanındaki majör maddelerden biri olan nikotin ise damarlarda daralmaya yol açarak dolaşım sistemini baskılayabilir, kan basıncını ve hipoksiyi arttırabilir. Karaciğer, böbrek, akciğer ve plasentadaki iskemik hasarlar üzerine yapılan son araştırmalar oksijen türevi serbest radikallerin, reperfüze hipoksik dokularda büyük miktarlarda üretildiğini ve bu radikallerin, hücre içi hasarların bir kısmından sorumlu olduğunu ortaya çıkarmıştır ${ }^{26}$. Birden fazla çalışmada sigara dumanının yol açtığı vasküler değişikliklerin hipoksiyle uyarılan pulmoner hipertansiyonla ilişkisi olduğu ve bu değişikliklerin inflamasyonun neden olduğu vasküler duvar hipertrofisinden kaynaklandığı belirtilmiştir ${ }^{27,28}$. Çalışmamızda tütün dumanı grubuna ait pulmoner vasküler duvar kalınlığında artış olduğu gözlendi. Bu kalınlık artışının tütün dumanı kaynaklı muhtemel hipoksiye bağlı olabileceğini düşünmekteyiz.

Vasküler endotelyal büyüme faktörü (VEGF) anjiogenezi stimüle eden, endotelyal hücrelere özgü bir mitojendir. VEGF' in akciğerlerde alveollerden ve bronşiyollerden, havayolları düz kas ve nötrofil hücrelerinden üretildiği tespit edilmiştir ${ }^{29}$. Sigara dumanının akciğer VEGF düzeylerine etki mekanizmasının doğrudan değil de, hipoksi ve inflamasyona yol açan etkileri ile açıklanabilir ${ }^{30}$. Oksidatif stres, hipoksi veya inflamatuar sitokinler ile anjiogenezin uyarılarak VEGF ve fibroblast büyüme faktörü gibi anjiogenik faktörlerin havayolu epitel ve düz kas hücrelerindeki ekspresyonunu ve salınımını indüklediği, bu faktörlerin damarlanma olayında, endotel hücrelerin çoğalıp göç ederek yeni endotelyal kanallar oluşmasını uyardığı bildirilmiştir ${ }^{31}$. Dokudaki artan VEGF seviyelerinin akciğer patofizyolojisinde rolü olduğu, pulmoner ödem ve hemoraji gibi birçok yan etkiye yol açtığı ortaya koyulmuştur ${ }^{32}$. Çalışmamızda tütün dumanı grubuna ait kesitlerde VEGF immünreaktivitesinin anlamlı oranda arttığı ve bu artışın tütün dumanı kaynaklı artan oksidatif stres kaynaklı olabileceği ve bilgilerle uyumlu olarak tütün dumanının dokuda yol açabileceği muhtemel hipoksiye bağlı olarak da VEGF reaktivitesinin artabileceğini düşünmekteyiz. Bu bulgular, VEGF etkisi ile bozulan alveoler yapının ciddi akciğer hastalıklarına yol açabileceğini, tütün dumanı maruziyeti boyunca VEGF'nin aşırı üretiminin pulmoner vasküler remodellenmesine katkı sunduğunu düşündürmektedir.

Tütün dumanı ile oluşan oksidatif stres, çoklu doymamış yağ asitlerinin oksidasyonuna ve 
akrolin, malondialdehid gibi reaktif karbonil türlerinin üretimine yol açar ${ }^{33}$. Bu nedenle sigara içenlerde peroksidasyon ürünü olan serum MDA düzeyleri yüksek beklenmektedir ${ }^{34}$. Bu çalışmada da tütün dumanı grubuna ait doku MDA değerlerinde artış olduğu, böylelikle tütün dumanı kaynaklı hasarların oksidatif stres kaynaklı olduğu belirlenmiştir. Bunun yanı sıra artan karbonil türlerin, akciğerlerdeki makrofaj, fibroblast ve epitel hücrelerinden VEGF salınımını indüklediği bildirilmiștir ${ }^{35}$. Bu bulgular da ROS ve a-ß-doymamış aldehitlerin işbirliği yaparak VEGF üretimini arttırmasina kanit niteliğindedir. Ayrıca VEGF'in vasküler geçirgenliği arttırarak akciğerlerde kandan nötrofilleri içeren lökosit infiltrasyonuna yardım ettiği ortaya koyulmuştur ${ }^{36}$. Çalışmamızda bu bilgilere uyumlu olarak dokudaki artan VEGF seviyelerinin pulmoner ödem ile artan inflamatuar hücrelerle ilişkili olabileceği kanaatindeyiz.

Sigaraya bağlı olarak oksidatif streste artış olduğu, oksidan/antioksidan dengesizliklerinin görüldüğü, plazma antioksidan seviyelerinin azaldığ 1 bilinmektedir ${ }^{37}$. Diyetle aldığımız endojen antioksidanların oksidatif stres nötralizasyonuna yardım ettiği, oksidatif stres indüklü patolojik anjiogenezi azalttığı, vasküler patolojinin önlenmesine katkı sağladığı rapor edilmiştir ${ }^{38}$. Diğer bir diğer çalışmada da fenolik komponentlerin ve yeşil çaydaki polifenollerin VEGF ekspresyonlarını düşürerek anjiogenezisi inhibe ettiği bildirilmiştir ${ }^{39}$. Son yllarda yapılan çalışmalarda ALA'nın lipit peroksidasyonunu inhibe ederek çeșitli dokularda potent antioksidan olarak davrandığı vurgulanmıştır ${ }^{40}$. Ayrıca ALA'nın mesane, göğüs, kolon, akciğer gibi çeșitli kanser türleri üzerine etkisi araştırıldığında çoğalan hücreleri, normal hücrelere etki etmeden basklladığı rapor edilmiştir ${ }^{41}$ Akciğer kanserinin ileri evresindeki hastalarda ALA tedavisinin, T hücre defektlerini düzelttiği ve $\mathrm{T}$ hücre fonksiyonlarını arttırdığı tespit edilmiştir ${ }^{42}$. Çalışmamızda tütün dumanı maruziyetine bağlı olarak artan VEGF'in angiogenezisi uyararak kanser patogenezinde rol alan damarlanma artışı için risk oluşturabileceği, ALA'nın ise antioksidan özelliği ile artan VEGF üretimini baskılayarak yeni damar oluşumunda önleyici rol alabileceği kanaatindeyiz.

Çıkar Çatışması Beyanı: Yazarlar çıkar çatışması olmadığını bildirmişlerdir.

Finansal Destek: Çalışma bütçesinin tamamı Fırat Üniversitesi Bilimsel Araştırma Projeleri Koordinasyon Birimi (FÜBAP)' nin TF. 16.06 proje no'lu kararı gereğince karşılanmıştır.

Declaration of Conflicting Interests: The authors declare that they have no conflict of interest.

Financial Disclosure: This study was supported by the foundation of scientific research projects (Project number: TF. 16.06)

\section{KAYNAKLAR}

1. World Health Organization. Tobacco Free Initiative. Protection from exposure to second-hand tobacco smoke. Policy recommendations. http://www.who.int/ tobacco/en/ (Erişim tarihi: 05.02.2018).

2. Environmental Tobacco Smoke Air Quality Guidelines Second Edition WHO Regional Office for Europe, Copenhagen, Denmark, 2000. http://www.euro. who.int/document/aiq/8_1ets.pdf(Erişim Tarihi:05.02.1018).

3. Besaratinia A, Pfeifer GP. Second-hand smoke and human lung cancer. Lancet Oncol 2008;9:657-63.

4. Glantz SA, Parmley WW. Passive smoking and heart disease. Epidemiology, physiology, and biochemistry. Circulation 991;83:1-12.

5. Türkiye Halk Sağlığı Kurumu. Küresel Yetişkin Tütün Araştırması Türkiye. Ankara: Anıl Matbaa, 2014.

6. WHO recommendations for the prevention and management of tobacco use and second-hand smoke exposure in pregnancy. World Health Statistics, 2013.

7. Küresel Yetişkin Tütün Araştırması Türkiye -T.C. Sağlık Bakanlığı Türkiye Halk Sağlığı Kurumu. Ankara 2012. 
8. Nakamura MU, Alexandre SM, Kuhn dos Santos JF, et al. Obstetric and perinatal effects of active and/or passive smoking during pregnancy. Sao Paulo Med J 2004;122:94-8.

9. U.S. Department of Health and Human Services. The Health Consequences of Smoking: A Report of the Surgeon General. Atlanta: U.S. Department of Health and Human Services, Centers for Disease Control and Prevention, National Center for Chronic Disease Prevention and Health Promotion, Office on Smoking and Health. 2004.

10. Le Cras TD, Spitzmiller RE, Albertine KH, et al. VEGF causes pulmonary hemorrhage, hemosiderosis, and air space enlargement in neonatal mice. Am J Physiol Lung Cell Mol Physiol 2004;287:134-42.

11. Lee KS, Park HS, Park SJ, et al. A prodrug of cysteine, L-2-oxothiazolidine-4-carboxylic acid, regulates vascular permeability by reducing vascular endothelial growth factor expression in asthma. Mol Pharmacol 2005;68:1281-90.

12. Goraca A, Huk-Kolega H, Piechota A. Lipoic acidbiological activity and therapeutic potential. Pharmacol Rep 2011;63:849-58.

13. Al Ghafli MHM, Padmanabhan R, Kataya $\mathrm{HH}$, et al. Effects of $\alpha$-lipoic acid supplementation on maternal diabetes-induced growth retardation and congenital anomalies in rat foetuses. Mol cell Biochem 2004;1-13.

14. Kılıç A, Uyanıkoğlu H, İncebıyık A. Rat Overinde İskemi-Reperfüzyon Üzerine N-Asetil Sistein ve Resveratrol'ün Koruyucu Etkisi. Dicle Med J 2016;43:229-36.

15. Balgetir F, Kocaman N. Deneysel Diyabetik Ratların Beyin Dokusunda İrisin İmmünreaktivitesi Üzerine Losartanın Etkileri. Firat Tıp Derg 2016;21:63-6.

16. Placer ZA, Cushmann LL, Johnson BC. Estimation of products of lipid peroxidation (as malondialdehyde) in biochemical systems. Analytical Biochemistry1966;16:359-64.

17. Mori Y, Limura K, Furukawa F, et al. Effect of cigarette smoke on the mutagenic activation of various carcinogens in hamsters. Mutat Res 1995;346:1-8.

18. De Marini DM, Shelton ML, Levine JG. Mutation spectrum of cigarette smoke condensate in Salmonella: comparison to mutation in smoking-associated tumors. Carcinogenesis 1995;16:2535-42.

19. Gupta S, Agarwal A, Banerjee J, et al. The role of oxidative stress in spontaneous abortion and recurrent pregnancy loss: a systematic review. Obstet Gynecol Surv 2007;62:335-47.

20. Burton GJ, Jauniaux E. Placental oxidative stress: from miscarriage to preeclapmsia. J Soc Gynecol Investig 2004;11:342-52.
21. Ziad S, Wajdy A, Darwish B. Effects of cigarette smoking on histology of trachea and lungs of albino rat. Res Opin Anim Vet Sci 2013;3:356-62.

22. Lobo V, Patil A, Phatak A, et al. Free radicals, antioxidants and functional foods: Impact on human health. Pharmacogn Rev 2010;4:118-26.

23. Dogan OM, Elagoz S, Ozsahin SF, et al. Pulmonary toxicity of chronic exposure to tobacco and biomass smoke in rats. Clinics 2011;66:1081-87.

24. Abbott LC, Winzer-Serhan UH. Smoking during pregnancy: lessons learned from epidemiological studies and experimental studies using animal models. Critical Reviews in Toxicology 2012;42:279-303.

25. Czekaj P, Pałasz A, Lebda-Wyborny T. Morphological changes in lungs, placenta, liver and kidneys of pregnant rats exposed to cigarette smoke. Int Arch Occup Environ Health 2002;75:27-35.

26. Kusterer K, Blochle C, Konrad T, et al. Rat liver injury induced by hypoxic ischemia and reperfusion: protective action by somatostatin and two derivatives. Regul Pept 1993;44:251-6.

27. Wright JL, Tai H, Dai J, et al. Cigarette smoke induces rapid changes in gene expression in pulmonary arteries. Lab Invest 2002;82:1391-8.

28. Wright JL, Churg A. Effect of long-term cigarette smoke exposure on pulmonary vascular structure and function in the guinea pig. Exp Lung Res 1991;17:9971009.

29. Christou H, Yoshida A, Arthur V, et al. Increased vascular endothelial growth factor production in the lungs of rats with hypoxia-induced pulmonary hypertension. Am J Respir Cell Mol Biol 1998;18:76876.

30. Rovina N, Papapetropoulos A, Kollintza A, et al. Vascular endothelial growth factor: an angiogenic factor reflecting airway inflammation in healthy smokers and in patients with bronchitis type of chronic obstructive pulmonary disease? Respir Res 2007;8:53.

31. Carmeliet P, Jain RK. Angiogenesis in cancer and other diseases. Nature 2000;407:249-57.

32. Kunig AM, Balasubramaniam V, Markham NE, et al. Recombinant human VEGF treatment tran siently increases lung edema but enhances lung structure after neonatal hyperoxia. Am J Physiol Lung Cell Mol Physiol 2006;291:1068-78.

33. Aldini G, Dalle-Donne I, Colombo R, et al. Lipoxidation-derived reactive carbonyl species as potential drug targets in preventing protein carbonylation and related cellular dysfunction. Chem Med Chem 2006;1:1045-58. 
34. Nadiger HA, Mathew CA, Sadasivudu B. Serum malondialdehyde (TBA reactive substance) levels in cigarette smokers. Atherosclerosis 1987;64:71-3.

35. Moretto N, Facchinetti F, Southworth T, et al. alpha, beta-Unsaturated aldehydes contained in cigarette smoke elicit IL-8 release in pulmonary cells through mitogen-activated protein kinases. Am J Physiol Lung Cell Mol Physiol 2009;296:839-48.

36. Edirisinghe I, Yang SR, Yao $\mathrm{H}$, et al. VEGFR-2 inhibition augments cigarette smoke-induced oxidative stress and inflammatory responses leading to endothelial dysfunction. Faseb J 2008;22:2297-310.

37. Duthie GG, Arthur JR, James WP. Effects of smoking and vitamin $\mathrm{E}$ on blood antioxidant status. Am J Clin Nutr 1991;53:1061-3.

38. Fotsis T, Pepper MS, Aktas E, et al. Flavonoids, dietary-derived inhibitors of cell proliferation and in vitro angiogenesis. Cancer Res 1997;57:2916-21.
39. Oak MH, El Bedoui J, Schini-Kerth VB. Antiangiogenic properties of natural polyphenols from red wine and green tea. J Nutr Biochem 2005;16:1-8.

40. Savitha S, Tamilselvan J, Anusuyadevi M, et al. Oxidative stress on mitochondrial antioxidant defense system in the aging process: Role of DL-a-lipoic acid and L-carnitine. Clin Chim Acta 2005;355:173-80.

41. Schwartz L, Guais A, Israel M, et al. Tumor regression with a combination of drugs interfering with the tumor metabolism: efficacy of hydroxycitrate, lipoic acid and capsaicin. Invest New Drugs 2013;31: 256-64.

42. Mantovani G, Maccio A, Melis G, et al. Restoration of functional defects in peripheral blood mononuclear cells isolated from cancer patients by thiol antioxidant alpha-lipoic acid and $\mathrm{N}$-acetyl cysteine. Int J Cancer 2000;86:842-7. 